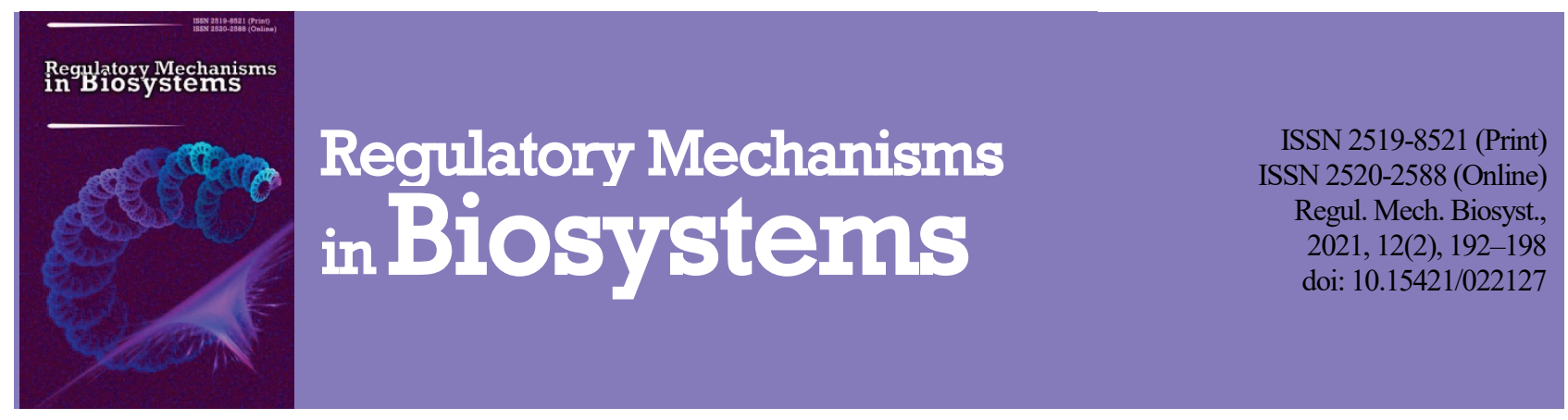

\title{
Micromorphology and anatomy of the flower of Zephyranthes candida (Amaryllidaceae)
}

\author{
O. S. Fishchuk \\ Lesya Ukrainka Eastern European National University, Lutsk, Ukraine
}

Article info

Received 27.03.2021

Received in revised form 01.05 .2021 Accepted 02.05.2021

\author{
Fishchuk, O. S. (2021). Micromorphology and anatomy of the flower of Zephyranthes candida (Amaryllidaceae). Regulatory Mechan- \\ isms in Biosystems, 12(2), 192-198. doi:10.15421/022127
}

Lesya Ukrainka

Eastern European

National University,

Voli pr., 13,

Lutsk, 43025, Ukraine.

Tel.: +38-066-310-81-07.

E-mail:

dracaenaok@ukr.net

The use of morphological features of flowers in the taxonomy of plants is becoming increasingly important. The structure of the Zephyranthes candida (Lindl.) Herb. flowers on permanent cross-sectional and longitudinal sections was studied using a light microscope. The genus Zephyranthes belongs to the subtribe Hippeastrinae Walp. tribe Hippeastreae Sweet., family Amaryllidaceae s.l. Microscopic studies of the flower are considered as a tool to identify hitherto unknown structural adaptations of plants to specialized pollination methods and to elucidate the first stages of fruit morphogenesis, as many features of the fruit appear at the flower stage. The morphometric parameters, morphology, anatomy, and vascular anatomy of the ovary were described by using the flower's transverse sections. Ten flowers of $Z$. candi$d a$ were sectioned using standard methods of Paraplast embedding and serial sectioning at $20 \mu \mathrm{m}$ thickness. Sections were stained with Safranin and Astra Blau and mounted in Eukitt. It was found that in the studied species the tepals have multi-bundle traces of 10-12 leading bundles. We consider the gynoecium of the studied species to be eusincarpous. The vascular system of the inferior ovary consists of three dorsal and three septal bundles, paired ventral bundles of carpels, which form ovule traces. For the first time, the presence of the following gynoecium zones was detected: a synascidiate structural zone with a height of about $360 \mu \mathrm{m}$ and a fertile symplicate structural zone with a height of about $1560 \mu \mathrm{m}$ and a hemisymplicate zone of $480 \mu \mathrm{m}$. Septal nectaries appear in the hemisymplicate zone and open with nectary split at the base of the style, the total height of the septal nectary is $760 \mu \mathrm{m}$. The ovary roof is $280 \mu \mathrm{m}$. Bifurcated dorsal and septal bundles of carpels have been identified, which can be considered as adaptations of the early stages of fruit morphogenesis to opening. Anatomical features of the ovary of $Z$. candida are numerous vascular bundles in the pericarpium, non-lignified endocarp at the flower stage, we consider as adaptations to the formation of juicy fruit. New data on the anatomical structure of the flower are a significant addition to the information on antecological and post-anthetic features of the studied species. Also, these data can be used in the construction of parsimony branches of the family Amaryllidaceae.

Keywords: flower anatomy; septal nectary; ovary; gynoecium; vascular bundle; vertical zonality; flower morphology.

\section{Introduction}

Molecular taxonomy of monocotyledonous plants is based solely on molecular data, occasionally morphological features of a flower are used to construct taxonomic systems. And such important features as the presence and height of the vertical ovary zones, the number of ovules in the locule, the features of vascular anatomy of the flower and the structure of septal nectaries should be included in the construction of phylogenetic trees. The integration of molecular phylogenetics data and evolutionary comparative morphology of a flower is a promising direction for the construction of a modern evolutionary system of orders, families, subfamilies and genera. The study of micromorphology and vascular anatomy of monocotyledonous flowers is a modern direction in the study of evolutionary morphology (Nuraliev \& Sokoloff, 2014; Odintsova \& Fishchuk, 2017). Molecular-phylogenetic reconstructions of the family Amaryllidaceae J. St.-Hil. has been carried out by many scientists Meerow et al. (2006), Chase et al. (2009), García et al. (2019).

The objects of our study were selected Zephyranthes candida, which is widely grown as an ornamental flowering plant. Genus Zephyranthes Herb. belongs to the subtribe Hippeastrinae Walp. tribes Hippeastreae Sweet., subfamily Amaryllidoideae s. s., family Amaryllidaceae (Chase et al., 2009; Takhtajan, 2009; Chase et al., 2016). Data from the molecular taxonomy of the studied genera confirm the monophilia of the tribe (Lledó et al., 2004). The genus Zephyranthes includes about 70 herbaceous species of small-bulb perennials that are common in the subtropical and tropi- cal regions of America, the mountains of Mexico, the sandy plateaus of Chile, and Southern Africa (Takhtajan, 2009). Characteristic features of the genus are hollow scape, terete, rarely retained entirely inside the bulb, single-flowered, spathe bracts fused and tubular below the middle (Meerow \& Snijman, 1998).

The study of alkaloids in members of the genus Zephyranthes is relevant (Centeno-Betanzos et al., 2021; Kohelová et al., 2021), in particular in Z. candida (Zhan et al., 2016; Zhan et al., 2017; Murphy et al., 2020), flavans with potential anti-inflammatory activities from $Z$. candida (Zhan et al., 2016; Nguyen et al., 2020), chlorotic ringspot virus infecting Z. candida in China (Wu \& Liu, 2017), the endosperm development and the variations of structures of embryo sacs (Chengqi, 2019).

It is proved that the embryo sac development in $Z$. candida follows the Polygonum type. The structure of the mature embryo sac in $Z$. candida is described and the behaviours of the synergids, the central cell and the antipodal cells are discussed (Ao et al., 20020). Mass propagation through direct and indirect organogenesis in three species of genus Zephyranthes and ploidy assessment of regenerants through flow cytometry were studied (Syeed et al., 2021). Effects of leaf area index and degree of canopy cover of green turf and ground cover plants on rainwater interception in Z. candida was examined by Zhang et al. (2018). New geophytes for Tunisian and North African alien flora and among them $Z$. candida have been studied by Mokni et al. (2020). Karyological investigation on three Zephyranthes species and its taxonomic significance was described by Bangladesh researchers (Dash et al., 2020). Taxonomy and reproductive 
biology of the genus Zephyranthes in Bangladesh were studied (Afroz et al., 2018). Phytochemistry and pharmacology of genus Zephyranthes were investigated by Katoch \& Singh (2015) and pharmacological properties by Francisco et al. (2017). A new species of Zephyranthes (Amaryllidaceae) from Mexico has been described by American and Mexican scientists (Spurrier et al., 2015). Taxonomic novelties in Southern Brazilian Amaryllidaceae were studied (Büneker \& Bastian, 2018). Genetic structure of Zephyranthes fosteri was described by Torres-Morán et al. (2019). Thus, the issues of reproductive biology, taxonomy and pharmacology of $Z$. candida attract considerable attention from modern researchers, but the anatomy and morphology of the flower, which are important for the analysis of pollination methods and post-anthesis morphogenesis (formation and fruit opening) remain unexplored.

The aim of our study was to elucidate the features of flower morphology and internal structure of the gynoecium, the structure of septal nectaries and to identify the vertical zonality of the gynoecium in members of the family Amaryllidaceae.

\section{Material and methods}

Plant material was collected in the A. V. Fomin Botanical Garden of the Taras Shevchenko National University of Kyiv and fixed in $70 \%$ alcohol. Ten $Z$. candida flower buds were dehydrated in t-butanol series $(20 \%, 30 \%, 50 \%, 70 \%, 100 \%-2 \mathrm{~h}$ each, the last one $24 \mathrm{~h})$ and stored in $100 \% \mathrm{t}$-butanol and Paraplast in the ratio 1:1. Infiltration was performed in Paraplast (Merck ${ }^{(B)}$ ) according to manufacturer's instructions (Barykina et al., 2004). Transverse and longitudinal sections of $20 \mu \mathrm{m}$ thickness were obtained with manual rotary microtome (MPS-2 (USSR)) and stained in Safranin $\left(\right.$ Sigma-Aldrich $^{\mathbb{R}}$ ) and Astra Blau $\left(\right.$ Merck $\left.^{\mathbb{R}}\right)$. Slides were mounted in "Eukitt" (Sigma-Aldrich $\left.{ }^{\mathbb{R}}\right)$ and images were obtained with an AMSCOPE 10MP digital camera attached to an AMSCOPE T490B10M(USA) microscope.

For the morphological analysis, measurements were made on at least 15 fresh flowers. We used the concept of vertical zonality of the gynoeciaum by Leinfellner (1950) to analyze the gynoecium's internal structure, which considers only the congenital fusion of the carpels. According to this concept, with the carpels' growth, the congenital multilocular synascidiate, unilocular symplicate, transitional hemisymplicate, and asymplicate (apocarpous) zones could be formed in the syncarpous gynoecium. In the conditions of incomplete fusion of carpels, a hemisyncarpous gynoecium with hemisynascidiate, hemisymplicate, and asymplicate zones form only in their outer part; later, the method was elaborated for monocots (Odintsova, 2013). The height of the zones of the gynoecium was measured according to the number of cross-sections.

\section{Results}

The flower of $Z$. candida is up to $6.6-7.0 \mathrm{~cm}$ long, slightly zygomorphic, white. The scape is $24-27 \mathrm{~cm}$ long and $0.4 \mathrm{~cm}$ in diameter, flowers are solitary. The bracts are two conical fused into one, forming a two-keel structure about $2.5 \mathrm{~cm}$ long, $1.2 \mathrm{~cm}$ wide and $0.8 \mathrm{~cm}$ at the base, leathery, brown. The pedicel is up to $0.8 \mathrm{~cm}$ long, about $0.3 \mathrm{~cm}$ in diameter (Fig. 1a). The perigonium is simple, linear. The flower tube is funnelshaped, about $0.3 \mathrm{~cm}$ long, $0.5 \mathrm{~cm}$ in diameter (Fig. 1f). The inner tepals are shorter than the outer (Fig. 5a). The outer tepals are 3.5, 3.6, $3.7 \mathrm{~cm}$ long and 1.0-1.1 cm wide, and the inner tepals are $3.2,3.4,3.4 \mathrm{~cm}$ long and $1.0 \mathrm{~cm}$ width (Fig. 1h).

The androecium in $Z$. candida consists of 6 stamens that have grown into a flower tube. The length of the inner stamens is $1.1 \mathrm{~cm}$, and the length of the outer stamens is $3.0 \mathrm{~cm}$. The filaments of the outer circle are $0.7-0.9 \mathrm{~cm}$ long, and the filaments of the inner circle are $1.0-1.1 \mathrm{~cm}$ and $0.05 \mathrm{~cm}$ in diameter (Fig. 1h). The anthers are bent at the apex, intrinsic, dorsifixed (Fig. 5b). The anthers of the outer stamens are $0.6 \mathrm{~cm}$ long and inner stamens $0.8 \mathrm{~cm}$ long, $0.1 \mathrm{~cm}$ in diameter. But the filaments attach to the anther in the outer and inner stamens below the middle (Fig. 1g).

The gynoecium of $Z$. candida is represented by three fused carpels. The ovary is ovoid, bright green $0.5 \mathrm{~cm}$ high and $0.4 \mathrm{~cm}$ in diameter (Fig. 1c, d), which turns into a slightly zygomorphic, green at the base, and above the white, s-shaped style 1.6 and $0.1 \mathrm{~cm}$ in diameter. The stigma is massive, bright green with lobes $0.2 \mathrm{~cm}$ long and $0.2 \mathrm{~cm}$ in diameter (Fig. 5b). The fruit is a berry-like capsule with flattened black seeds.

In Z. candida in the upper part of the peduncle, at the base of the flower tube, in the filaments and in the ovary wall there are idioblasts with cellular inclusions - raphids (Fig. 3). They are absent in the tops of the free tepals, the connective and the style. The stomata are presented on the surface of the inferior ovary wall (Fig. 3). The protoplast of epidermal cells contains chloroplasts. Epidermal cells are elongated, prosenchymal, often straight-walled. The upper membrane of the ovary, in contact with the environment is thickened and cutinized. The outer layers of cutin form a very stable protective water-repellent lamina - the cuticle. Its thickness depends on lighting and water supply. Uneven layering of cutin forms a species-specific pattern - a bumpy cuticle in $Z$. candida. The studied species is characterized by the presence of anomocytic morphological type of stomata complexes. This means that the cells around the closing cells do not differ from the basal ones. A stoma in $Z$. candida is a hole in the epidermis, which is the main component of the stomata system and includes: closing cells, slit-like intercellular space - stomatal slit, as well as adjacent epidermal cells or specialized by-cells (Fig. 3a). Closing cells are paired bean-shaped, oriented parallel to the airway; contain photosynthetic chloroplasts with starch grains and numerous mitochondria. The membranes are unevenly thickened: dorsal, adjacent to the side cells, thin, easily stretched; abdominal, facing the slit, thickened, often their outer and inner parts form the characteristic cuticular spurs or beaks that cover the cavities the outer (front) and inner (rear) courtyards of the respiratory slit (Fig. 3b). Depending on the state of the organism and external factors, the closing cells are stretched or contracted in the tangential direction and control the size of the airway. The lateral cells of the stomata are functionally and morphologically different from the basal ones (Fig. 3c). The wall of the inferior ovary is formed of about 20 layers of cells. The inner tepals consist of 15 layers of cells, the outer tepals consist of 17 layers of cells.

In the gynoecium of $Z$. candida we distinguish the following structural zones: the synascidiate structural zone, about $360 \mu \mathrm{m}$ high (Fig. 1c) and the fertile symplicate structural zone (Fig. 1d), which is about $1560 \mu \mathrm{m}$ high, and the hemisymplicate zone $480 \mu \mathrm{m}$ (Fig. 1e). The roof of the ovary is $280 \mu \mathrm{m}$ (Fig. 4b). Septal nectaries appear in the hemisymplicate zone (Fig. 2d) and open with nectary slits at the base of the style (Fig. 1f), the total height of the septal nectary is $760 \mu \mathrm{m}$. In the transversal sections, the septal nectary looks like three slits ("lilioid" septal nectary). The nectary epidermis is glandular on the whole of the nectary surface. In its lower portion (in hemisymplicate zone), it has a common epidermis, three nectary cavities are united with the non-secretory epidermis in the center of the ovary (Fig. 2d). The septal nectary comprises two structures: the septal nectary body and the nectary split where nectar can be released outside. The septal nectary body reaches half of the ovarian radius; in the ovary roof the septal body becomes slightly undulate. Narrow septal grooves on the ovary surface are connected with the nectary splits at the base of the style (Fig. 4b).

The septal nectaries in $Z$. candida are relatively small (Fig. 2d), consisting of isodiametrical cells that are slightly elongated in parallel to the surface of the nectary and very short cells of lobe-like shape, perpendicular to it, with protruding outer walls. Vascular bundles pass in the middle or in the immediate vicinity of the nectary, they direct the lateral branches directly into the nectary parenchyma, where they end blindly. It should be noted that these vascular bundles are mostly found only in the most developed central part of the nectary, but are absent at its edges. We consider this is specialization, the vascular bundles of septal nectaries that supplied the nectary cells. The vascular bundle ends in the nectary parenchyma, containing the xylem located outside.

The peduncle in $Z$. candida at the base contains 12 vascular bundles (Fig. 1a), which are reorganized above into a vascular cylinder, at the level of the receptacle from which depart septal vascular bundles and dorsal vascular bundles and above it divided on tepal traces (Fig. 1b). Dorsal and septal vascular bundles are two-bundle. In the center there are 12 vascular bundles - roots of a ventral complex (Fig. 1c). Higher, these vascular bundles are reorganized in pairs and supplied the ovules - the ventral bundles of carpels (Fig. 1d). There are many ovules in each locule (Fig. 4a). On a cross-section in each locule are two ovules, the trace of ovule is one-bundle. 


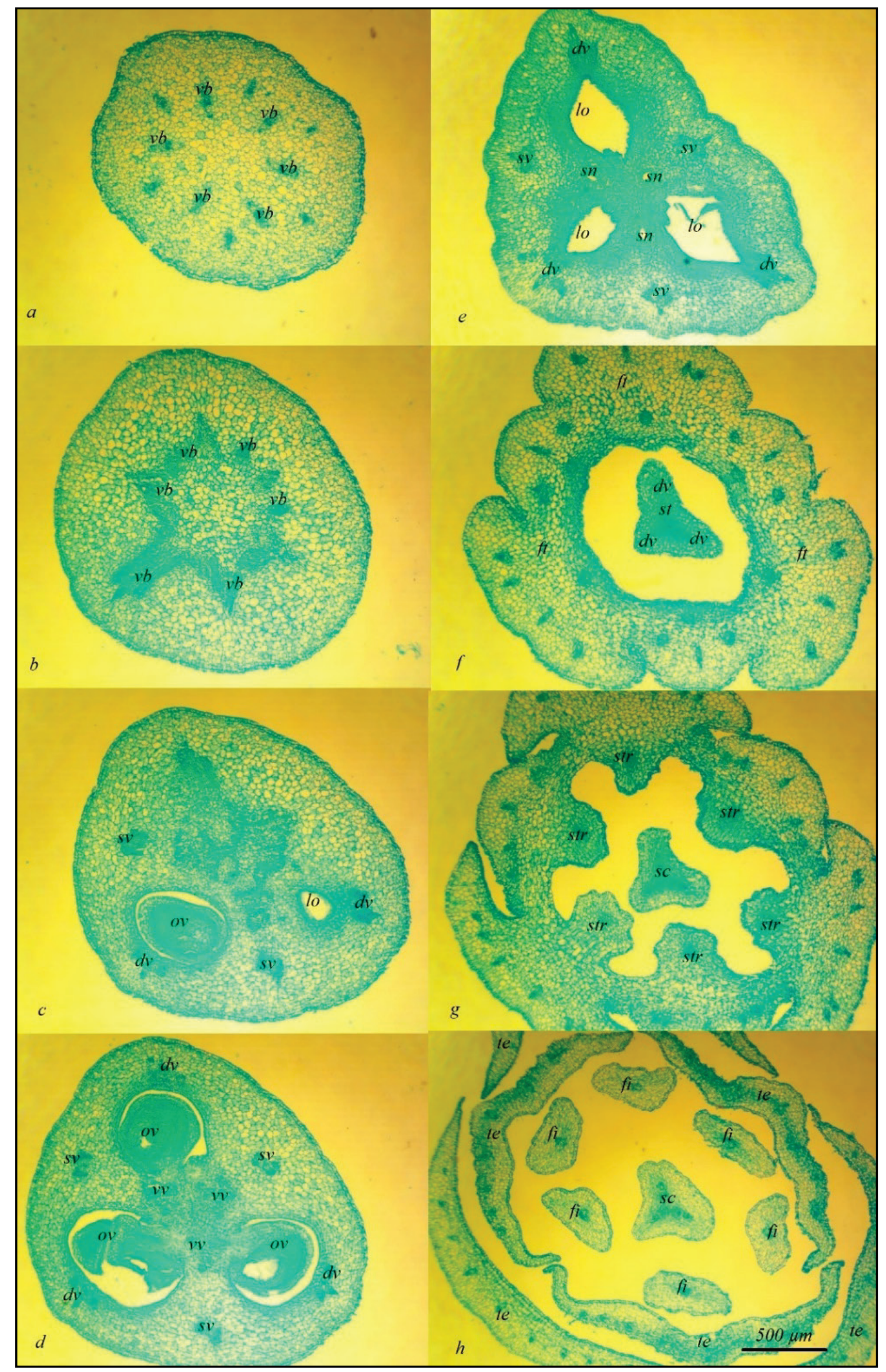

Fig. 1. Ascending series of transversal sections of the flower Zephyranthes candida: $a-b$-pedicel; $c-e$-inferior ovary; $c$-synascidiate zone, $d$-symplicate zone; $e$-hemisymplicate zone; $f$ - flower tube and style; $g$ - flower tube ending; $h$ - free tepals, filaments and style; $d v$-dorsal vein; $f i$ - filament; $l o$ - ovary locule; $o v$ - ovule; str-stamen trace; $s c$-style channel; $s v$ - septal vein; $s t$-style; $t e$ - tepal; $v b$-vascular bundle; $v v$ - ventral vein 


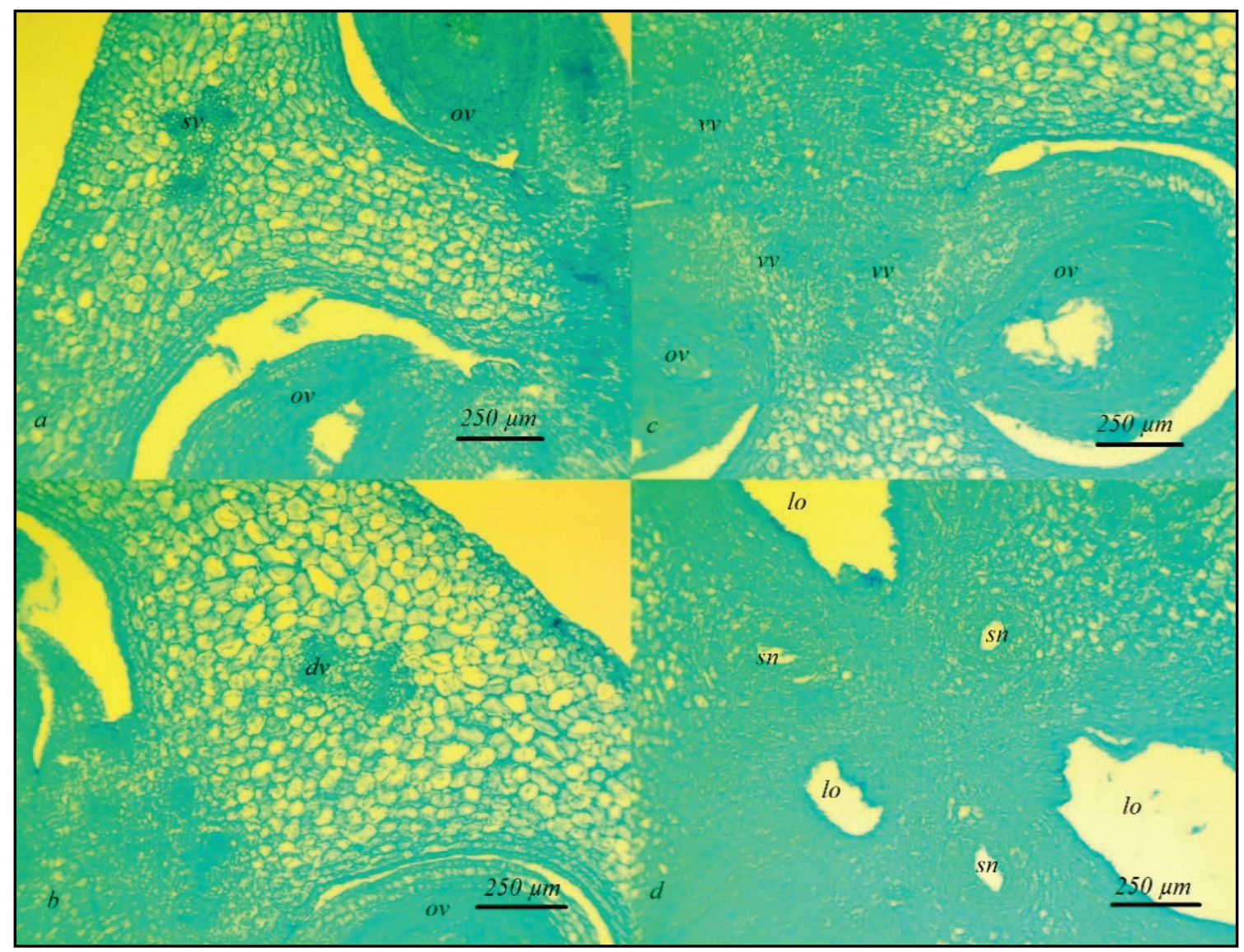

Fig. 2. Floral parts of Zephyranthes candida: $a$ - ovary wall with septa attached, septal vascular bundle and additional bundles in wall aerial parenchyma; $b$-ovary wall in the median part of the carpel, dorsal vein composed of two bundles and additional veins are visible; $c$ - central part of the ovary, ventral vascular bundles are visible; $d$-central part of the ovary with septal nectaries; $d v$ - dorsal vein; $o v$-ovule; $l o$-locule; $s v$ - septal vein; $v v$-ventral vein

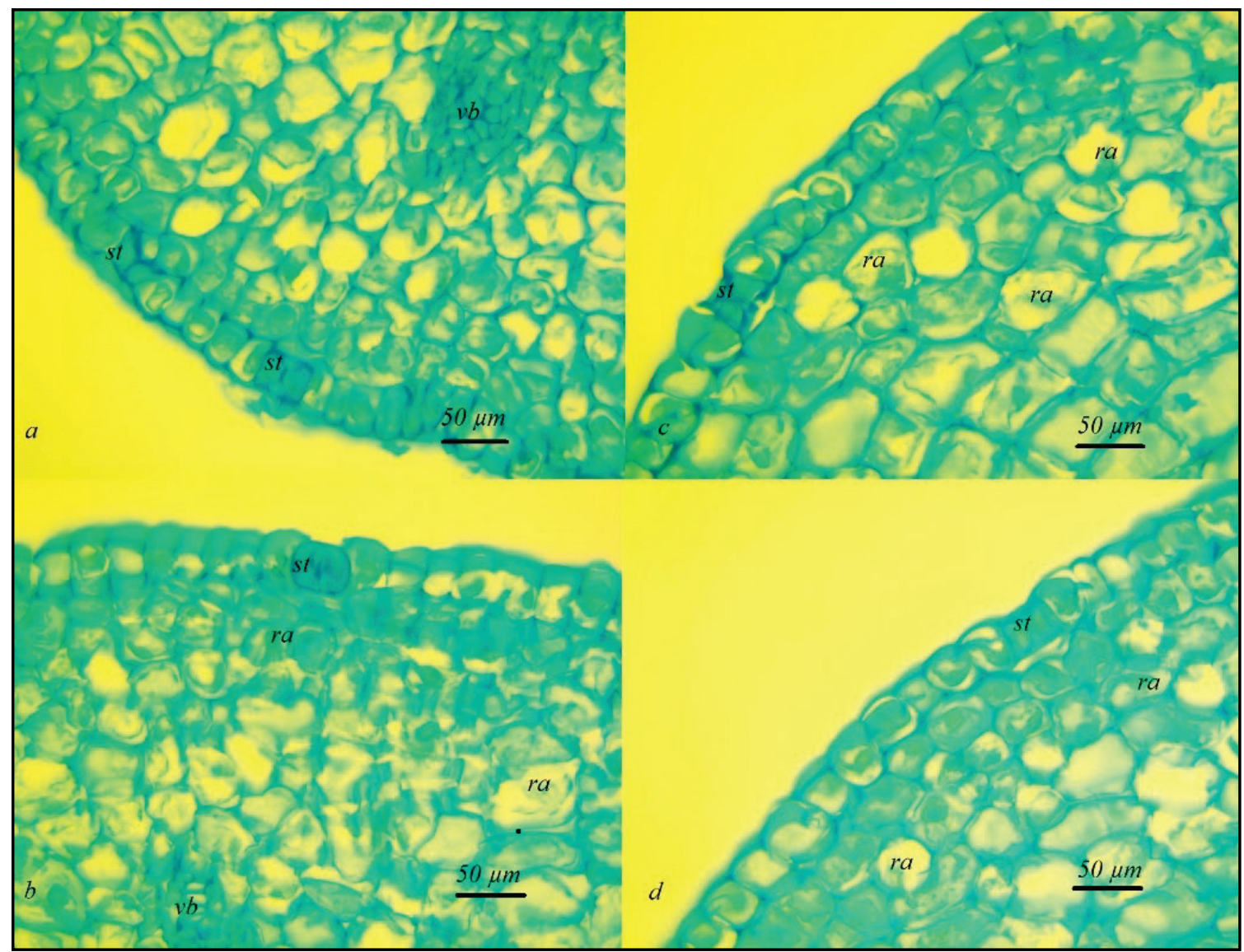

Fig. 3. Raphids and stomata in the distal parenchyma of the ovary wall of Zephyranthes candida: $r a$-raphids; $s t$-stomata; $v b$-vascular bundle 


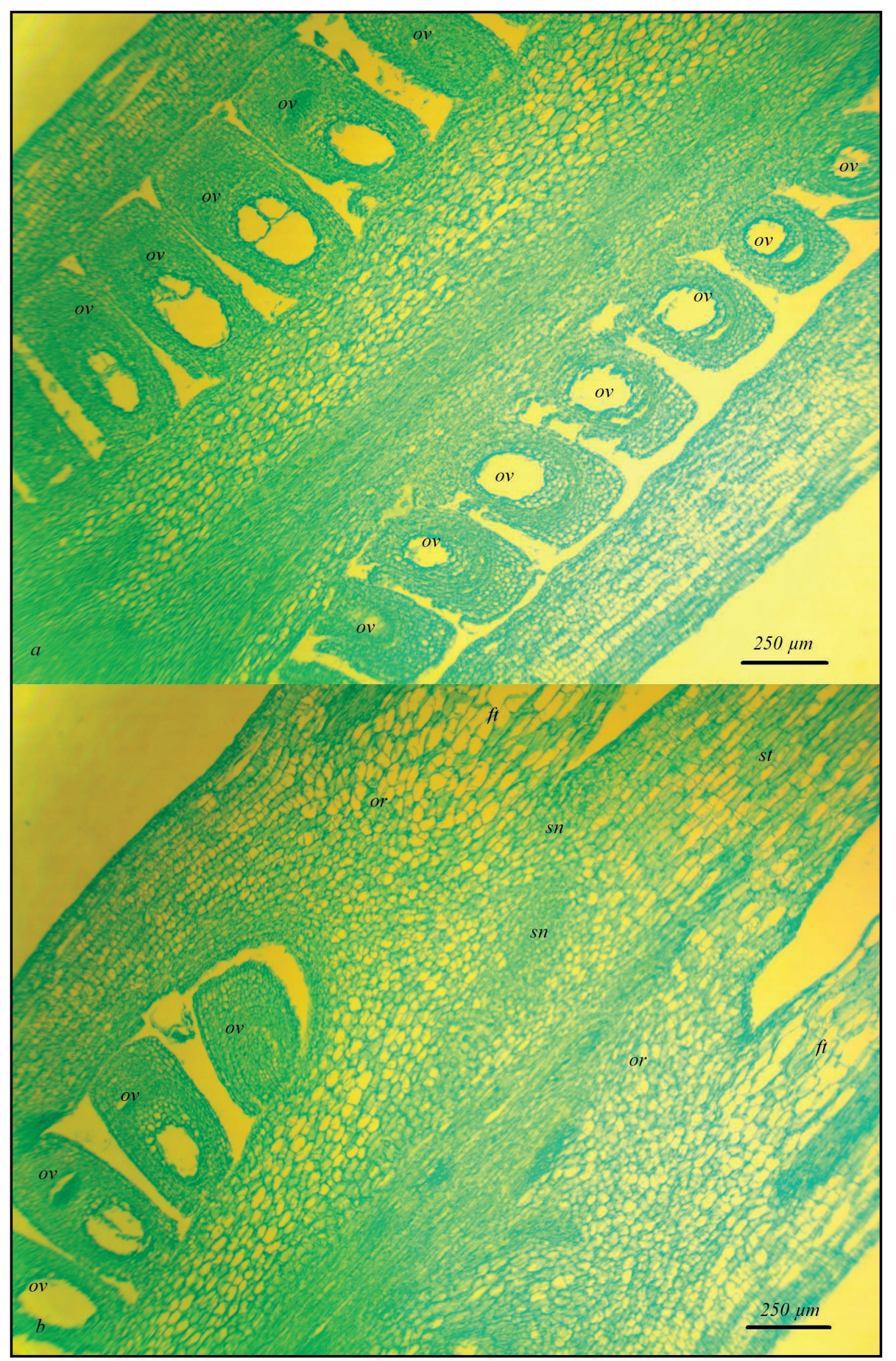

Fig. 4. Longitudinal sections of the ovary of Zephyranthes candida:

$f t$ - flower tube; $o v$ - ovule; or - ovary roof; $s n$-septal nectary; $s t$-style; on $b$ septal nectary is visible

Above the locules, the ventral vascular bundles of the carpel, in the septa merge with the dorsal vascular bundles and form a dorsal vein (Fig. 1f). At the level of the flower tube there is a branching of the vascular bundles, as traces of the outer tepals and inner tepals (Fig. 1f, g). Traces of outer tepals have 10 vascular bundles, traces of inner tepals have 12 vascular bundles. Above, vascular bundles of the inner tepals are vascularized to form a continuous vascular tissue (Fig. 1h). Traces of stamens are branching off from traces of tepals, the trace of the stamen is single-bundle (Fig. 5b).

\section{Discussion}

The gynoecium consists of three united carpels in Z. candida, the style is slender, with punctiform, capitate, or 3-lobed stigma, ovary 3-locular, with from several to many ovules per locule. Nectaries are septal or
(Galantheae) perigonal (secreted from the distal part of the inner perianth segments). Ovules are anatropous or hemitropous, bitegmic or rarely (Amaryllis and Nerine) unitegmic or (Crinum) ategmic, crassinucellate or rarely (Crinum, Narcissus, Zephyranthes) tenuinucellate, mostly with parietal cell. Female gametophyte of Polygonum type, rarely of Adoxa-type (Takhtajan, 2009). Flowers are (sub)erect, actinomorphic, the tube short or long. Stamens are usually biseriate in length. The style is trifid or obscurely 3-lobed. Capsule papery with numerous or few, black flattened or compressed, D-shaped or wedge-shaped seeds (Meerow \& Snijman, 1998).

Three species of Zephyranthes Herb. viz. Z. candida, Z. carinata Herb. and $Z$. tubispatha Herb. were cytotaxonomically studied to characterize and elucidate probable evolutionary relationship among them. These species were found to possess different chromosome number and karyotype formula (Dash et al., 2020). Megasporogenesis and megagametogenesis in Z. candida (Lindl.) Herb. (Amaryllidaceae) were 
observed by means of conventional paraffin sections. The functional megaspore becomes a mononucleate embryo sac and develops through three subsequent mitotic divisions into a seven-celled/eight-nucleate embryo sac (Ao et al., 2016). The genus Zephyranthes Herb. is revised along with its pollination mechanism, seed germination and vegetative propagation. Detailed taxonomy of four Zephyranthes species occurring in Bangladesh, namely, Z. atamasco (L.) Herb., Z. candida, Z. carinata and $Z$. tubispatha was studied with their updated nomenclature, important synonyms, phenology, specimens examined, habitat, distribution, economic value and mode of propagation. Pollination investigation reveals that all studied species of Zephyranthes are self-pollinated (Afroz et al., 2018).

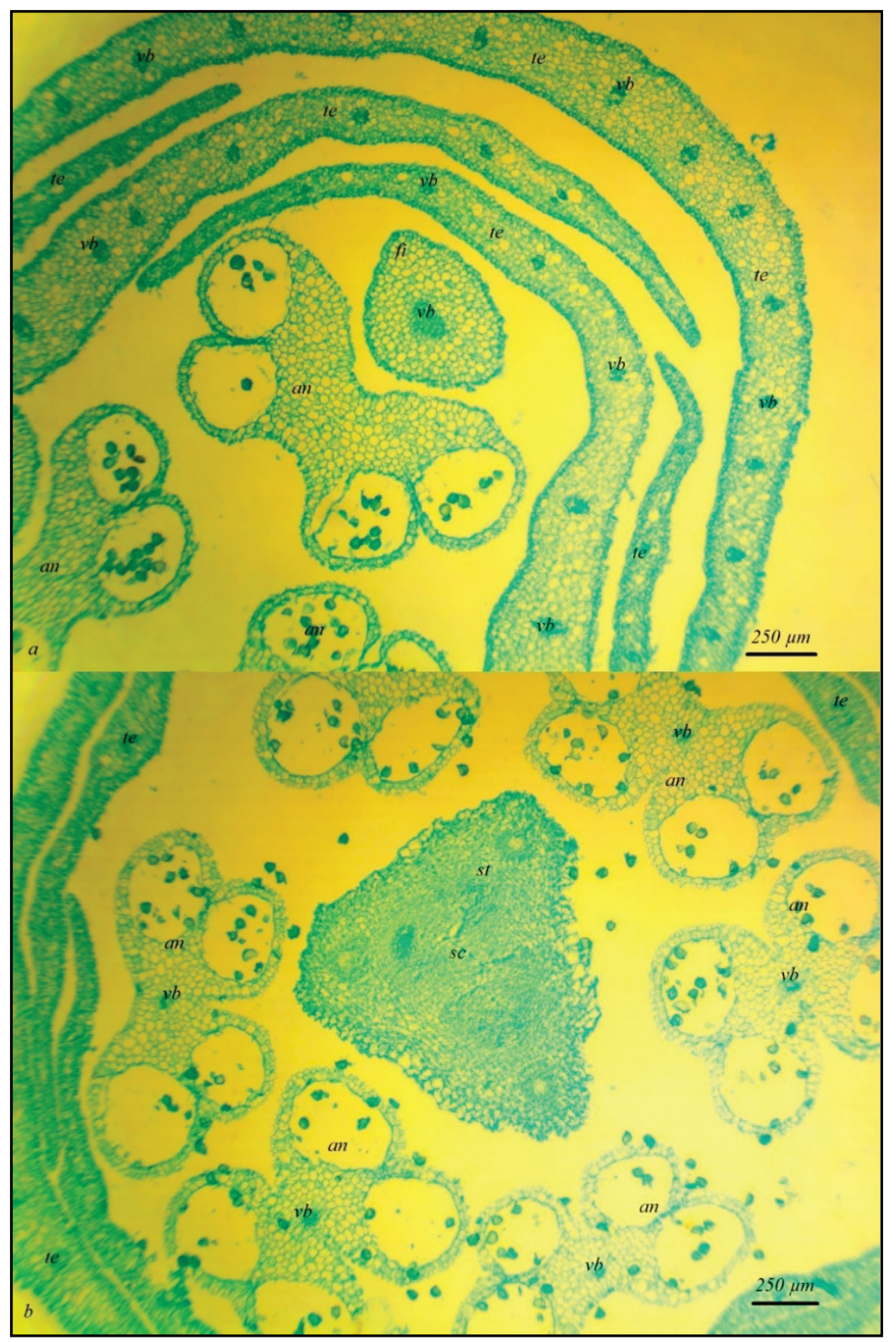

Fig. 5. Ascending series of transversal sections of the perigonium Zephyranthes candida: $a$-free tepals, filament and anthers;

$b$ - free tepals, anthers and style; $a n$ - anthers; $f i$ - filament; $s c$ - style channel; $s v$ - septal vein; $s t$-style; $t e$ - tepal; $v b$ - vascular bundle

According to Daumann (1970), the genus Zephyranthes has an internal septal nectary. He established the presence of epidermal septal nectaries in Z. candida. In general, the family Amaryllidaceae is characterized by the presence of septal nectaries (Daumann, 1970; Meerow \& Snijman, 1998; Takhtajan, 2009).

For monocotyledonous plants, common patterns of nectarines have been established - the absence of nectary flowers disks in superior ovary, nectary secretion through the cuticle rather than through nectary stomata, significant distribution of septal nectaries among lilioid monocotyledons and their frequent flowers from nectar-flower to pollen-flower (Smets et al., 2000). For the family Amaryllidaceae, central-angular placentation is indicated (Meerow \& Snijman, 1998). We found three vertical zones in the ovary of the studied species: a synascidiate structural zone $(360 \mu \mathrm{m})$, a fertile symplicate structural zone $(1560 \mu \mathrm{m})$ and a hemisymplicate zone $(480 \mu \mathrm{m})$. Septal nectaries appear in the hemisymplicate zone and open with a nectary split at the base of the style, the total height of the septal nectary is $760 \mu \mathrm{m}$. The ovary roof is $280 \mu \mathrm{m}$. We consider the gynoecium of the studied species to be eusincarpous in the sense of Leinfellner (1950), with symplicate and hemisymplicate fertile zones of the ovary. Shamrov (2010) came to similar conclusions in studying the development of the gynoecium in species of the genus Allium, which now belongs to the family Amaryllidaceae. 
We found new features of the anatomical structure of the flower of $Z$. candida, the presence of raphids and stomata in the peduncle, at the base of the flower tube, in the stamens and in the wall of the inferior ovary and stomata in the wall of the ovary and a double trace of dorsal and septal vascular bundles, a large number of vascular bundles in the tepals. A double dorsal vein was also found by us in Galanthus nivalis and Leucojum vernum (Fishchuk \& Odintsova, 2020). In Hippeastrum striatum traces of dorsal and septal bundles of the carpel are two-bundle too (Fishchuk, 2021).

\section{Conclusion}

The results of our research allowed us to deepen the knowledge about the micromorphological and anatomical features of the flower of $Z$. candida, in particular, the anatomical structure of the tepals, vertical zonality and type of gynoecium were specified. The anatomical structure of the ovary of $Z$. candida is characterized by a berry-like capsule with varying degrees lignified tissues reduction in the pericarpium. The juicy nature of the fruit is supported by the presence of numerous vascular bundles in the pericarpium, multi-bundle traces of tepals. The ovary revealed features of the early stages of fruit morphogenesis and adaptation to disclosure differentiation of mesocarp and endocarp cells, bifurcated dorsal and septal bundles of carpels. We assume that the listed features of the flower structure are related to the offer of pollen as a reward to the pollinator. Because the ovary is the structural basis of the fruit, histological differentiation of the ovary wall reflects the features of the subsequent morphogenesis of the fruit. Also, the studied features can be used in taxonomy.

\section{References}

Afroz, S., Rahman, M., \& Hassan, M. (2018). Taxonomy and reproductive biology of the genus Zephyranthes Herb. (Liliaceae) in Bangladesh. Bangladesh Journal of Plant Taxonomy, 25(1), 57-69.

Ao, C., Wang, L. Y., Sun, H., Lin, J. T., \& Chen, Y. C. C. C. (2016). Megasporogenesis and megagametogenesis in Zephyranthes candida (Amaryllidaceae), with special notes on the behavior of the synergids, the central cell and the antipodal cells. Phyton, 56(1), 91-101.

Barykina, R. P., Veselova, T. D., Deviatov, A. G., Djalilova, H. H., Ijjina, G. M., \& Chubatova, N. V. (2004). Spravochnik po botanicheskoy mikrotehnike [Handbook of botanical microtechniques]. Izdatelstvo Moskovskogo Universiteta, Moscow (in Russian).

Büneker, H. M., \& Bastian, R. E. (2018). Taxonomic novelties in Southern Brazilian Amaryllidaceae - II: Zephyranthes comunelloi a new species from Santa Catarina; and lectotypification of Zephyranthes mesochloa Herb. ex Lindl. Balduinia, 62, 1-8.

Centeno-Betanzos, L. Y., Reyes-Chilpa, R., Pigni, N. B., Jankowski, C. K., TorrasClaveria, L., \& Bastida, J. (2021). Plants of the 'Libellus de medicinalibus indorum herbis' from Mexico 1552, Zephyranthes fosteri (Amaryllidaceae) alkaloids. Chemistry and Biodiversity, 18, e2000834.

Chase, M. W., Christenhusz, M. J. M., Fay, M. F., Byng, J. W., Judd, W. S., Soltis, D. E., Mabberley, D. J., Sennikov, A. N., Soltis, P. S., \& Stevens, P. F. (2016). The angiosperm phylogeny group. An update of the angiosperm phylogeny group classification for the orders and families of flowering plants APG IV. Botanical Journal of the Linnean Society, 181, 1-20.

Chase, M. W., Reveal, J. L., \& Fay, M. F. (2009). A subfamilial classification for the expanded asparagalean families Amaryllidaceae, Asparagaceae and Xanthorrhoeaceae. Botanical Joumal of the Linnean Society, 161(2), 132-136.

Chengqi, A. (2019). The endosperm development and the variations of structures of embryo sacs: Unravelling the low fecundity of Zephyranthes candida (Amaryllidaceae). Plant Biosystems, 153(5), 673-678.

Dash, C. K., Rahman, M. O., \& Sultana, S. S. (2020). Karyological investigation on three Zephyranthes species and its taxonomic significance. Cytologia, 85(2), 163-168.

Daumann, E. (1970). Das Blütennektarium der Monocotyledonen unter besonderer Berücksichtigung seiner systematischen und phylogenetischen. Bedeutung Feddes Repertorium, 80(7-8), 463-590.

Fishchuk, O. (2021). Comparative flower morphology in Hippeastrum striatum (Lam.) H. E. Moore. (Amaryllidaceae). Ukrainian Journal of Ecology, 11(1), 273-278.

Francisco, L. (2017). A small flower with expansive energy: A proving of Zephyranthes rosea. Homoeopathic Links, 30(2), 112-113.
García, N., Meerow, A. W., Arroyo-Leuenberger, S., Oliveira, R. S., Dutilh, J. H., Soltis, P. S., \& Judd, W. S. (2019). Generic classification of Amaryllidaceae tribe Hippeastreae. Taxon, 68(3), 425-612.

Katoch, D., \& Singh, B. (2015). Phytochemistry and pharmacology of genus Zephyranthes. Medicinal and Aromatic Plants, 4(4), 212.

Kohelová, E., Mařiková, J., Korábečný, J., Hulcová, D., Kučera, T., Jun, D., Chlebek, J., Jenčo, J., Šafratová, M., Hrabinová, M., Ritomská, A., Malaník, M., Peřinová, R., Breiterová, K., Kuneš, J., Nováková, L., Opletal, L., \& Cahlíková, L. (2021). Alkaloids of Zephyranthes citrina (Amaryllidaceae) and their implication to Alzheimer's disease: Isolation, structural elucidation and biological activity. Bioorganic Chemistry, 107, 104567.

Leinfellner, W. (1950). Der Bauplan des Syncarpen Gynoeceums. Oesterreichische. Botanische Zeitschrift, 97(3-5), 403-436.

Meerow, A. W., \& Snijman, D. A. (1998). Amaryllidaceae. In: Kubitzki, K., Huber, H., Rudall, P. J., Stevens, P. S., \& Studzel, T. (Ed.). The families and genera of vascular plants. III. Flowering plants: Monocotyledons: Lilianae (except Orchidaceae). Springer, Berlin. Pp. 83-110.

Meerow, A. W., Francisco-Ortega, J., \& Schnell, R. J. (2006). Phylogenetic relationships and biogeography within the Eurasian clade of Amaryllidaceae based on plastid ndhF and nrDNA ITS sequences: Lineage sorting in a reticulate area? Systematic Botany, 31(1), 42-60.

Mokni, R. E., \& Khalifa, K. H. (2020). More new geophytes for Tunisian and North African alien flora. Flora Mediterranea, 30, 185-196.

Murphy, P. J., Tibble-Howlings, J., Kowalczyk, R. M., \& Stevens, K. (2020). Synthesis of zephycandidine A from haemanthamine. Tetrahedron Letters, 61(16), 151785.

Nguyen, K. V., Ho, D. V., Le, N. T., Phan, K. V., Heinämäki, J., Raal, A., \& Nguyen, H. T. (2020). Flavonoids and alkaloids from the rhizomes of Zephyranthes ajax Hort. and their cytotoxicity. Scientific Reports, 10, 22193.

Nuraliev, M. S., \& Sokoloff, D. D. (2014). Vaskulyarnaya anatomiya tsvetka kak istochnik informatsii ob evolyutsii pokryitosemennyih rasteniy: Istoriya izucheniya i sovremennyie predstavleniya [Floral vascular anatomy as a source of information on evolution of Angiosperms: History of study and current views]. Botanicheskiy Zhumal, 99(2), 129-158 (in Russian).

Odinczova, A. (2013). Dva osnovnyh typy septalnyh nektamykiv odnodolnyh [Two main types of septal nectaries in monocotyledons]. Visnyk Lvivskogo Universytetu, Seriya Biologichna, 61, 41-50 (in Ukrainian).

Odintsova, A., \& Fishchuk, O. (2017). The flower morphology in three Convallariaceae species with various attractive traits. Acta Agrobotanica, 70(1), 17051719 .

Shamrov, I. I. (2010). The peculiarities of syncarpous gynoecium formation in some monocotyledonous plants. Botanical Journal, 95(8), 1041-1070.

Smets, E. F., Ronse, De Craene, L. P., Caris, P., \& Rudall, P. (2000). Floral nectaries in monocotyledons: Distribution and evolution. Monocots II: Systematics and Evolution. CSIRO, Melbourne. Pp. 230-240.

Spurrier, M. A., Smith, G. L., Flagg, R. O., \& Serna, A. E. (2015). A new species of Zephyranthes (Amaryllidaceae) from Mexico. Novon, 24(3), 289-295.

Syeed, R., Mujib, A., Malik, M. Q., Mamgain, J., Ejaz, B., Gulzar, B., \& Zafar, N. (2021). Mass propagation through direct and indirect organogenesis in three species of genus Zephyranthes and ploidy assessment of regenerants through flow cytometry. Molecular Biology Reports, 48, 513-526.

Takhtajan, A. (2009). Flowering plants. Springer, Dordrecht.

Torres-Morán, M. I., Velasco, P., Almaraz-Abarca, N., Anaya- Covarnubias, J. Y., \& Velasco-Ramírez, A. (2019). Genetic structure of Zephyranthes fosteri, specie with ornamental and medicinal potential in Mexico. BIOtecnia, 21(2), 5-10.

Wu, B. W., \& Liu, Y. T. (2017). First report of Hippeastrum chlorotic ringspot virus infecting Zephyranthes candida in China. Plant Disease, 101(11), 1960-1960.

Zhan, G., Liu, J., Zhou, J., Sun, B., Aisa, H. A., \& Yao, G. (2017). Amaryllidaceae alkaloids with new framework types from Zephyranthes candida as potent acetylcholinesterase inhibitors. European Joumal of Medicinal Chemistry, 127, $771-780$.

Zhan, G., Qu, X., Liu, J., Tong, Q., Zhou, J., Sun, B., \& Yao, G. (2016). Zephycandidine $\mathrm{A}$, the first naturally occurring imidazo[1,2-f] phenanthridine alkaloid from Zephyranthes candida, exhibits significant anti-tumor and anti-acetylcholinesterase activities. Scientific Reports, 6, 33990.

Zhan, G., Zhou, J., Liu, R., Liu, T., Guo, G., Wang, J., Xiang, M., Xue, Y., Luo, Z., Zhang, Y., \& Yao, G. (2016). Galanthamine, plicamine, and secoplicamine alkaloids from Zephyranthes candida and their anti-acetylcholinesterase and antiinflammatory activities. Joumal of Natural Products, 79(4), 760-766.

Zhan, G., Zhou, J., Liu, T., Zheng, G., Aisa, H. A., \& Yao, G. (2016). Flavans with potential anti-inflammatory activities from Zephyranthes candida. Bioorganic and Medicinal Chemistry Letters, 26(24), 5967-5970.

Zhang, Y., Qiao, L., \& Wang, J. (2018). Effects of leaf area index and degree of canopy cover of green turf and ground cover plants on rainwater interception. Nature Environment and Pollution Technology, 17(2), 563-568. 